\title{
Expression of p16 in Conjunctival Intraepithelial Neoplasia Does Not Correlate with HPV-Infection
}

\author{
Claudia Auw-Haedrich ${ }^{*}, 1$, Gottfried Martin ${ }^{1}$, Helga Spelsberg ${ }^{2}$, Rainer Sundmacher ${ }^{3}$, \\ Nikolaus Freudenberg ${ }^{4}$, Philip Maier ${ }^{1}$ and Thomas Reinhard ${ }^{1}$ \\ ${ }^{1}$ Eye Hospital, Albert-Ludwigs-University, Killianstr. 5, D-79106 Freiburg, Germany \\ ${ }^{2}$ Eye Center, Clinic Pallas Otten, Switzerland \\ ${ }^{3}$ Eye Hospital, Heinrich-Heine-University, Moorenstr. 5, D-40125 Düsseldorf, Germany \\ ${ }^{4}$ Institute for Pathology, Albert-Ludwigs-University, Breisacherstr. 115a, D-79106 Freiburg, Germany
}

\begin{abstract}
The aim of our study was to identify the frequency of expression of p16 $6_{\mathrm{INK} 4 \mathrm{a}}(\mathrm{CDKN} 2 \mathrm{~A})$ and HPV (human papilloma virus) in different grades of conjunctival intraepithelial neoplasia (CIN).

Twelve specimens including CIN I (2), II (3), III (5), and CIN with beginning invasion (2), as well as 15 control specimens, were stained with antibodies against $\mathrm{p} 16_{\mathrm{INK} 4 \mathrm{a}}$ and MIB1. The presence of HPV was examined by PCR.

p16 as well as MIB1 were significantly elevated in CIN compared to control specimens $(\mathrm{p}<0.01)$ without correlation with the differentiation grade. Only two cases with CIN grade 3 contained HPV 16.

As few control specimens also showed increased p16 $6_{\text {INK4a }}$ expression, p16 $6_{\text {INK4a }}$ seems not to be a very reliable marker for the exact determination of CIN. It could serve as an additional diagnostic tool besides the morphological characterization. Our study suggested that $\mathrm{p} 16_{\mathrm{INK} 4 \mathrm{a}}$ elevation is not associated with HPV infection.
\end{abstract}

Keywords: p16, conjunctival intraepithelial neoplasia, HPV.

\section{INTRODUCTION}

Conjunctival intraepithelial neoplasia (CIN) presents as a spectrum from simple dysplasia to carcinoma in situ. CIN commonly arises in the limbal region and particularly occurs in elderly males who have lived in areas exposed to high levels of UV-B radiation [1], an assumed main risk factor in addition to HPV16 [2], especially in persons with pale skin, pale iris and propensity to sunburn [3]. UV light is thought to cause DNA damage and the formation of pyrimidine dimers [4].

Recently our immunohistochemical analysis showed a significantly higher expression of p63 in CIN and carcinoma compared to the normal specimens without correlation with the differentiation grade and MIB-1-rate [5], indicating its independence from cell cycle progression. p63 is a homologue of the tumor suppressor gene p53 first cloned by Yang A et al. in 1998 [6], which functions instead as an oncogene [7]. Here we were interested in investigating another cell cycle marker (in addition to MIB-1) in CIN, which could be a promising candidate to increase diagnostic specificity and safety.

In cervical intraepithelial neoplasia, p16 $6_{\mathrm{INK} 4 \mathrm{a}}(\mathrm{CDKN} 2 \mathrm{~A}$, cyclin-dependent kinase inhibitor $2 \mathrm{~A}$ ) was shown to indicate malignancy and progression into carcinoma $[8,9]$. p16 $6_{\text {INK4a }}$ restrains the progression of the cell cycle by inhibiting the activity of CDK (cyclin dependent kinase) 4, the latter

*Address correspondence to this author at the Eye Hospital, AlbertLudwigs-University, Killianstr. 5, D-79106 Freiburg, Germany; Tel: 0049771-2704001; Fax: 0049-761-2704057;

Email: claudia.auw-haedrich@uniklinik-freiburg.de targets $\mathrm{pRb}$ for phosphorylation and abolish $\mathrm{pRb}$ inhibition of $\mathrm{E} 2 \mathrm{~F}$, driving cell cycle progression. In the presence of HPV infection, the HPV E7 protein binds to $p R b$ and displaces E2F with subsequent E2F activation and cell cycle progression from the G1 to S phase and mitosis (Fig. 1).

Due to $\mathrm{pRb}$ inactivation, $\mathrm{p} 16$ increases and becomes immunohistochemically detectable [10-12].

The aim of our study was to assess the frequency of expression of $\mathrm{p} 16_{\mathrm{INK} 4 \mathrm{a}}$ and HPV in different grades of conjunctival intraepithelial neoplasia in order to find out if HPVvaccination could also be important in order to prevent this disease.

\section{MATERIAL AND METHODS}

The study was approved by the ethic comitee of the Albert-Ludwig University Freiburg, Germany, written informed consent was obtained from the study participants. 12 conjunctival specimens (see also Table 1) excised from the bulbar conjunctiva with the suspicion of conjunctival intraepithelial neoplasia (CIN) and 14 macroscopically normal postmortem conjunctival specimens and 1 conjunctival specimen with slight inflammatory changes (postmortem time $18.2 \mathrm{~h}$ in average, range $0-26.2 \mathrm{~h}$ ) were fixed in $4 \%$ formaldehyde in $0.075 \mathrm{M}$ phosphate buffer for $24 \mathrm{~h}$, dehydrated in increasing concentrations of ethanol (70\%-99\%) and infiltrated with paraffin (Merck, Darmstadt, Germany) at $60^{\circ} \mathrm{C}$. Sections of $3 \mu \mathrm{m}$ thickness were cut and floated on deionized water at $45^{\circ} \mathrm{C}$, and single sections were mounted on Superfrost Plus glass slides (Menzel-Glaser, Germany). Slides were subsequently dried at $60^{\circ} \mathrm{C}$ for $1 \mathrm{~h}$. The haema- 


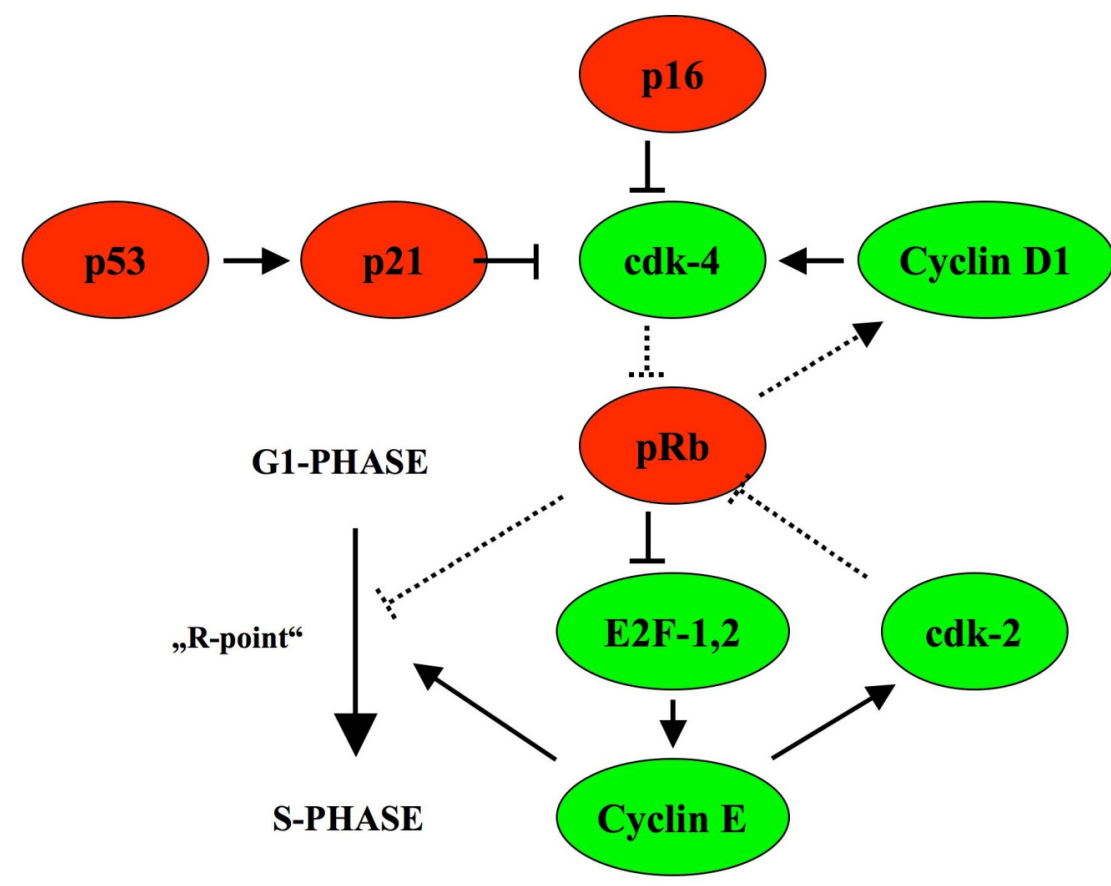

Fig. (1). p16 $6_{\mathrm{INK} 4 \mathrm{a}}$ restrains cell cycle progression by inhibiting the activity of CDK (cyclin dependent kinase) 4 and is upregulated in case cell cycle progression takes place due to phosphorylation of $\mathrm{pRb}$ (with permission of Graefes from [13]).

Table 1. Clinical Data of the CIN Specimens

\begin{tabular}{|c|c|c|c|c|c|c|c|}
\hline No & Age & Gender & Clinical Findings & $\begin{array}{l}\text { Treatment Prior } \\
\text { to Excision }\end{array}$ & $\begin{array}{l}\text { Risk } \\
\text { Factors }\end{array}$ & Proposed Pathogenic Sequence & Tumor Location \\
\hline 1 & 79 & $\mathrm{f}$ & Chronic conjunctivitis & Cromoglycic acid & None & Primary CIN? & Limbus, $16 \times 6 \times 4 \mathrm{~mm}$ \\
\hline 2 & 67 & $\mathrm{~m}$ & Conjunctivitis & None & None & Primary CIN? & Nasal and temporal limbus \\
\hline 3 & 39 & $\mathrm{~m}$ & Red eye & Vit A ointment & None & Primary CIN? & Temporal limbus \\
\hline 4 & 73 & $\mathrm{~m}$ & Corneal neoplasia & None & None & $\begin{array}{l}\text { Possibly primary CIN developing } \\
\text { from a pinguecula }\end{array}$ & $\begin{array}{l}\text { Corneal at the limbus, adjacent } \\
\text { to pinguecula }\end{array}$ \\
\hline 5 & 61 & $\mathrm{~m}$ & Corneal neoplasia & None & None & Primary CIN? & $\begin{array}{c}\text { Medial limbus with corneal } \\
\text { part }(2-3 \mathrm{~mm}) \\
10 \times 5 \times 2 \mathrm{~mm}\end{array}$ \\
\hline 6 & 64 & $\mathrm{~m}$ & $\begin{array}{l}\text { At least } 4 \text { years ocular } \\
\text { surface problems with } \\
\text { circular pannus }\end{array}$ & $\begin{array}{l}\text { Topical steroids, } \\
\text { antiviral ointment }\end{array}$ & HPV 16 & $\begin{array}{l}\text { Malignant transformation due to } \\
\text { HPV } 16\end{array}$ & $\begin{array}{c}\text { Limbus with corneal part at } 7 \\
\text { and } 12 \mathrm{~h}\end{array}$ \\
\hline 7 & 67 & $\mathrm{~m}$ & $\begin{array}{l}\text { "Pterygium" since at } \\
\text { least } 3 \text { years with } \\
\text { unusual extension }\end{array}$ & None & None & $\begin{array}{l}\text { Primary CIN mimicking pterygium } \\
\text { or CIN developing from altered } \\
\text { epithelium of a pterygium }\end{array}$ & $\begin{array}{l}\text { Medial limbus with corneal } \\
\text { part }(2 \mathrm{~mm})\end{array}$ \\
\hline 8 & 56 & $\mathrm{f}$ & $\begin{array}{l}\text { Atypical Pterygium } \\
\text { with whitish plaque } \\
\text { and vascularisation }\end{array}$ & None & HPV 16 & $\begin{array}{l}\text { Malignant transformation due to } \\
\text { HPV } 16\end{array}$ & Limbus, $11 \times 7 \times 1 \mathrm{~mm}$ \\
\hline 9 & 61 & $\mathrm{~m}$ & Red eye & None & None & Primary CIN? & $\begin{array}{l}\text { Medial limbus with corneal } \\
\text { part }(2 \mathrm{~mm})\end{array}$ \\
\hline 10 & 53 & $\mathrm{~m}$ & $\begin{array}{l}\text { Superficial vasculari- } \\
\text { sation onto the cornea }\end{array}$ & None & $\begin{array}{l}\text { Explosion } \\
\text { injury } 30 \\
\text { years previ- } \\
\text { ously }\end{array}$ & $\begin{array}{l}\text { DNA-damage due to the trauma and } \\
\text { malignant transformation during } \\
\text { repair phase }\end{array}$ & $\begin{array}{l}\text { Limbus with corneal part } \\
\qquad(2 \mathrm{~mm})\end{array}$ \\
\hline 11 & 29 & $\mathrm{~m}$ & Whitish neoplasia & $\begin{array}{l}1991 \text { tectonic } \\
\text { keratoplasty due } \\
\text { to malignancy, } \\
1992 \text { rekerato- } \\
\text { plasty due to } \\
\text { corneal melting }\end{array}$ & $\begin{array}{l}\text { Xeroderma } \\
\text { pigmento- } \\
\text { sum, UV-B } \\
\text { radiation }\end{array}$ & $\begin{array}{l}\text { DNA-damage and malignant trans- } \\
\text { formation due to UV-B radiation and } \\
\text { defective repair mechanisms }\end{array}$ & $\begin{array}{l}\text { Limbus with corneal part } \\
\text { (4mm) } 4 \times 4 \times 2\end{array}$ \\
\hline 12 & 67 & $\mathrm{~m}$ & Red eye & $\begin{array}{l}\text { Dexpanthenol eye } \\
\text { drops }\end{array}$ & None & Primary CIN? & Medial limbus \\
\hline
\end{tabular}


toxylin-eosin stained patient slides were diagnosed histologically as follows: 2 CIN grade I (up to $25 \%$ of the whole thickness of the specimen shows dysplasia), $3 \mathrm{CIN}$ grade II (25-75\% of the whole thickness of the specimen shows dysplasia), 5 CIN grade III (more than $75 \%$ of the whole thickness of the specimen shows dysplasia, this category also includes carcinoma in situ), and 2 CIN with beginning invasion (showing minute interruption of the basal lamina and dysplastic cells below the basal lamina level). The 15 macroscopically normal conjunctival specimens and 12 CIN specimens were stained immunohistochemically using the avidin biotin method including antigen retrieval using a microwave oven for 10 minutes at $\mathrm{pH} 6.0$, before the mouse monoclonal antibodies p16 ${ }^{\mathrm{INK} 4 \mathrm{a}} \mathrm{Ab}-4$ (clone $16 \mathrm{P} 04 / \mathrm{JC} 2$, Lab Vision Corporation, Fremont, USA) and Ki-67 (clone MIB-1, DAKO, Glostrup, Denmark) were applied for $2 \mathrm{~h}$. The negative controls used only showed occasional and slight cytoplasmic background staining. Cells that were considered positive for either $16^{\text {INK4a }}$ or MIB-1 clearly showed a reddish stained nucleus, and some displayed additional cytoplasmic positive staining.

At least 500 cells per specimen of representative vertical sections of the specimens at a magnification of 200x were counted, and the proportion of positively stained cells for each antibody was calculated. Statistical calculation was performed using the Kruskal-Wallis non-parametric test.

\section{HPV Detection by PCR}

DNA from 1-3 $5 \mu \mathrm{m}$ paraffin sections was extracted as follows: paraffin was removed by xylol and the sections were recovered by centrifugation and drying. $100 \mu \mathrm{l}$ of 100 $\mathrm{mN} \mathrm{NaOH}$ were added and the sections were incubated for 1 $\mathrm{h}$ at $95^{\circ} \mathrm{C}$. After the samples cooled, the solution was neutralized by adding $11 \mu 1$ of $1 \mathrm{M} \mathrm{NaH} 2 \mathrm{PO} 4.1-2 \mu 1$ were used in a $20 \mu \mathrm{l}$ PCR reaction containing $200 \mu \mathrm{M}$ dNTPs, $500 \mathrm{nM}$ primer mix PGMY11 (GCACAGGGACATAACAATGG, GCGCAGGGCCACAATAATGG, GCACAGGGACATAA
TAATGG, GCCCAGGGCCACAACAATGG, GCTCAGG GTTTAAACAATGG [14], $500 \mathrm{nM}$ primer GP6+ (GAAAA ATAAACTGTAAATCATATTC [15], and $2 \mathrm{U}$ Taq. Our primers, taken from the literature, bind at the conserved region of the $\mathrm{L} 1$ gene. The PCR program was 2 min incubation at $94^{\circ} \mathrm{C}, 40$ cycles of $94^{\circ} \mathrm{C}$ for $30 \mathrm{~s}, 55^{\circ} \mathrm{C}$ for $30 \mathrm{~s}$, and $72^{\circ} \mathrm{C}$ for $30 \mathrm{~s}$, and $5 \mathrm{~min}$ incubation at $72^{\circ} \mathrm{C}$. B-actin (CTACAATGAGCTGCGTGTGG, CGGTGAGGAT CTTCATG AGG) was used as a control. $2 \mu 1$ of the PCR product were diluted to $100 \mu 1$, of which $2.5 \mu 1$ were used for the second PCR with the primers GP5+ (TTTGTTACTGT GGTAGATACTAC) and GP6+. The second PCR reaction was adjusted to an annealing temperature of $40^{\circ} \mathrm{C}$ for $60 \mathrm{~s}$ and elongation at $72^{\circ} \mathrm{C}$ for $90 \mathrm{~s}$. Fragments of approximately 132 $\mathrm{bp}$ were isolated from the agarose gel and cloned into pBluescript (Stratagene, Amsterdam, The Netherlands). At least 3 clones were selected for each fragment and sequenced. All sequences showed a HPV fragment flanked by vector sequences. Sensitivity of the PCR was checked with a sample known to contain HPV. As we used nested PCR, we had a very sensitive as well as specific detection system which was commonly reported in the literature. In situ hybridization would have been an important supplementary method to detect HPV, which could not be performed due to lack of tissue in most of our CIN cases.

\section{RESULTS (TABLES 2 AND 3)}

\section{p16 Expression in Normal Conjunctival Specimens}

Most of the normal conjunctival specimens showed stronger p16 expression in the basal layers, compared to the more superficial cell layers (Fig. 2); few specimens were almost or completely negative for p16 expression (Fig. 3). The proportion of p16-positive cells in the normal postmortem conjunctiva and the conjunctival specimen with inflammatory changes varied between 0 and $51.8 \%$, and the mean was calculated at $16.4 \%$.

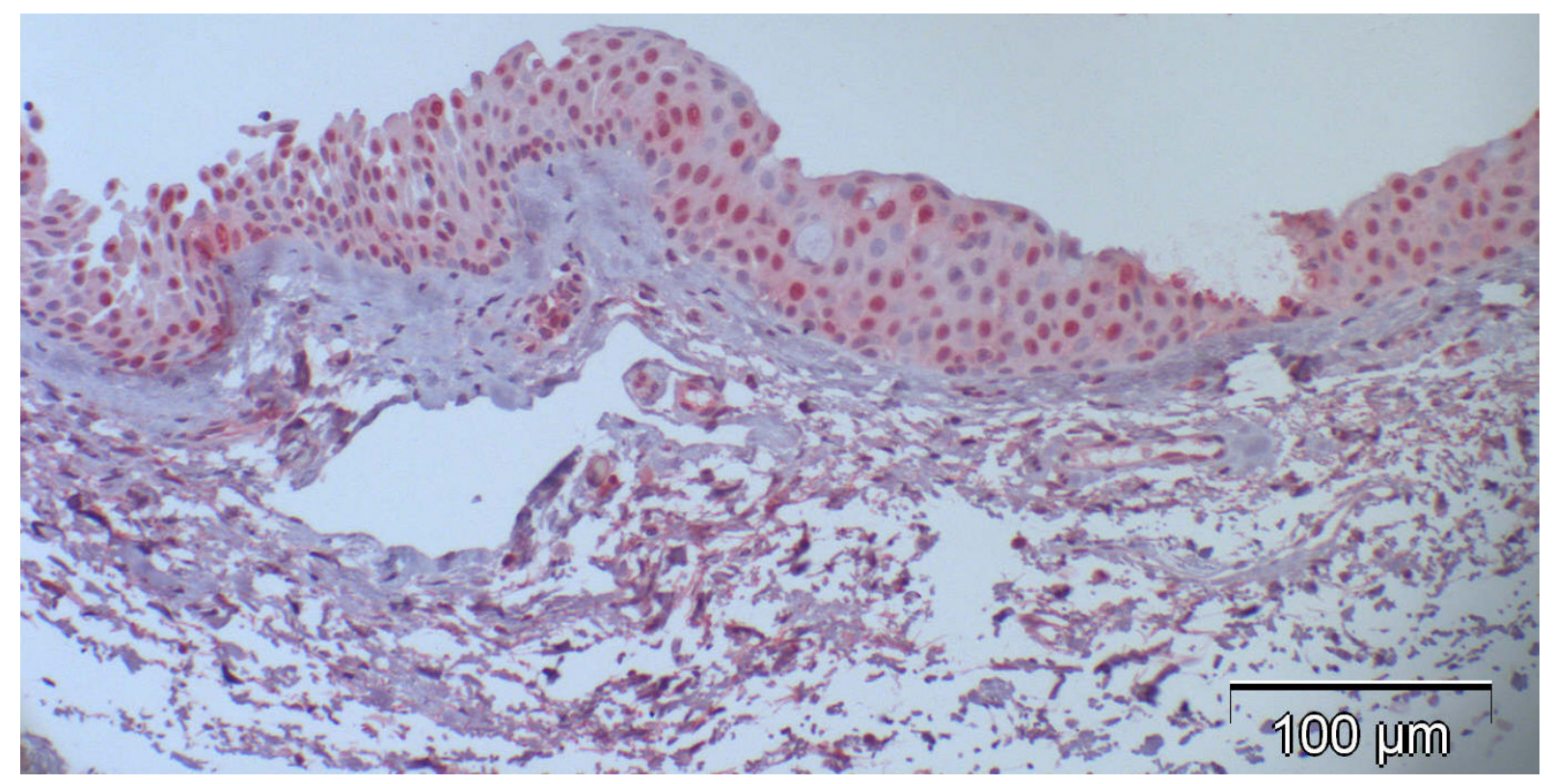

Fig. (2). Case 5 from Table 2 (normal control): 27\% are p16-positive cells, located throughout all epithelial layers with stronger staining of the basal and parabasal layer compared to the more superficial cell layers; some stromal cells show heavy background staining. 


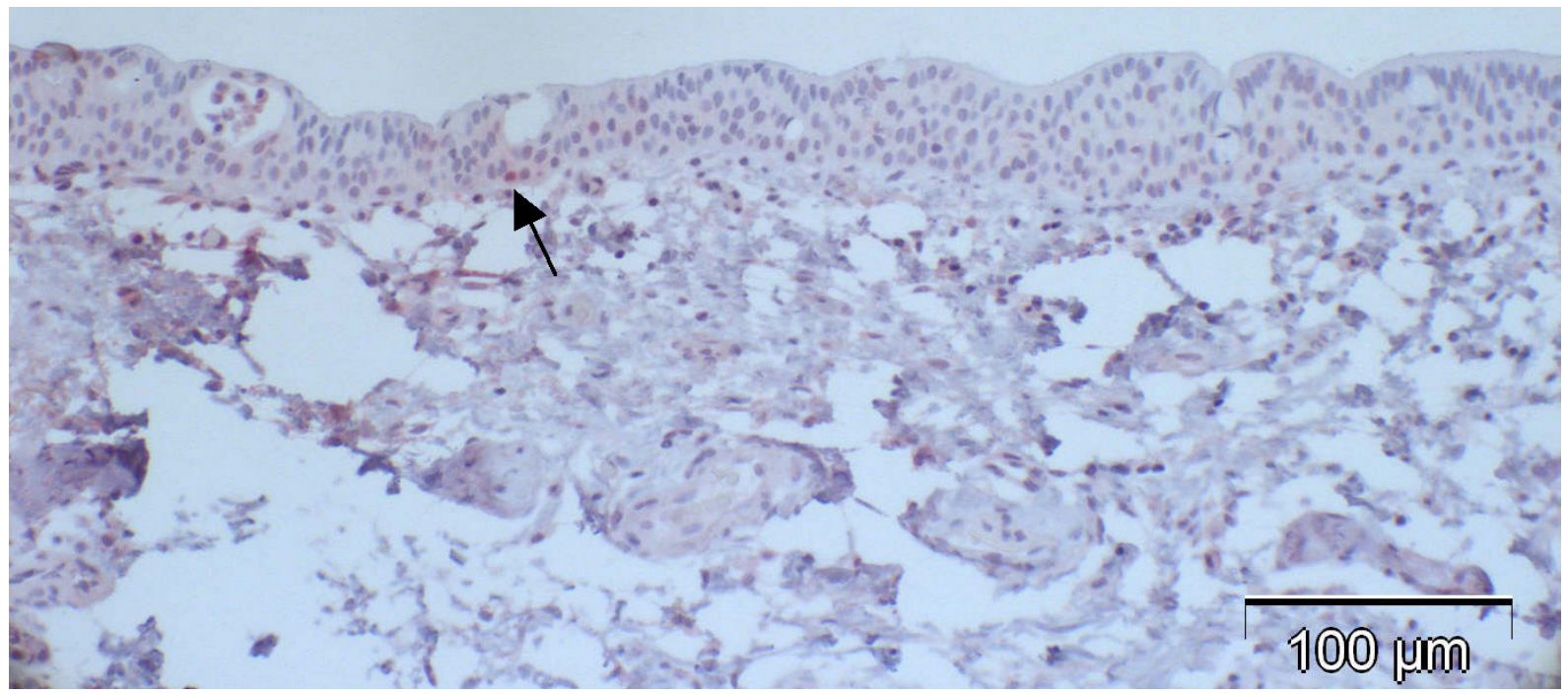

Fig. (3). Case 2 from Table 2 (normal control): almost negative p16 expression despite positive staining for p63 in a previous study [5] indicating functioning immunoreactivity of the specimen (arrow: positive nucleus).

\section{p16 Expression in CIN}

In contrast to observations in normal specimens, many of the CIN specimens stained positive for $\mathrm{p} 16$, exhibiting a similar trend to that in normal specimens, with a stronger intensity in the basal layers compared to the superficial layers (Fig. 4a-d).

The percentage of p16-positive cells in the CIN specimens was higher than that in normal specimens, and varied between 27.2 and $83.9 \%$, with the mean at $53.6 \%$. Notably, p16 expression was significantly elevated in CIN samples compared to the control specimens $(\mathrm{p}<0.001$, Fig. (5)). No correlation was found between p16 expression and the differentiation grade (correlation coefficient 0.2).

\section{MIB-1 Expression in Normal Conjunctival Specimens}

Analysis of MIB-1 expression revealed that the control specimens only contained 0 and $0.2 \%$ MIB- 1 positive cells among all specimens. Neither the expression of p16 nor
MIB-1 seemed to depend on the postmortem time, which ranged between 0 and 26.2 hours (mean of 18.2 hours).

\section{MIB-1 Expression in CIN}

Analysis of CIN samples revealed that MIB-1 expression was elevated in the dysplastic specimens, though not to the extent of p16 expression (Fig. 6).

The percentage of MIB-1 positive cells varied between 2.8 and $29.9 \%$, the mean being $11.8 \%$, a significant increase compared to the control specimens $(\mathrm{p}<0.001)$. Neither a correlation between differentiation grade and MIB-1 positive staining (correlation coefficient 0.2 ) nor between p16 and MIB-1 expression (correlation coefficient 0.4) was found.

\section{HPV Positivity in Normal Conjunctival Specimens and CIN}

None of the 15 control specimens were found to contain HPV, while $\beta$-actin expression was detected in 14 of the

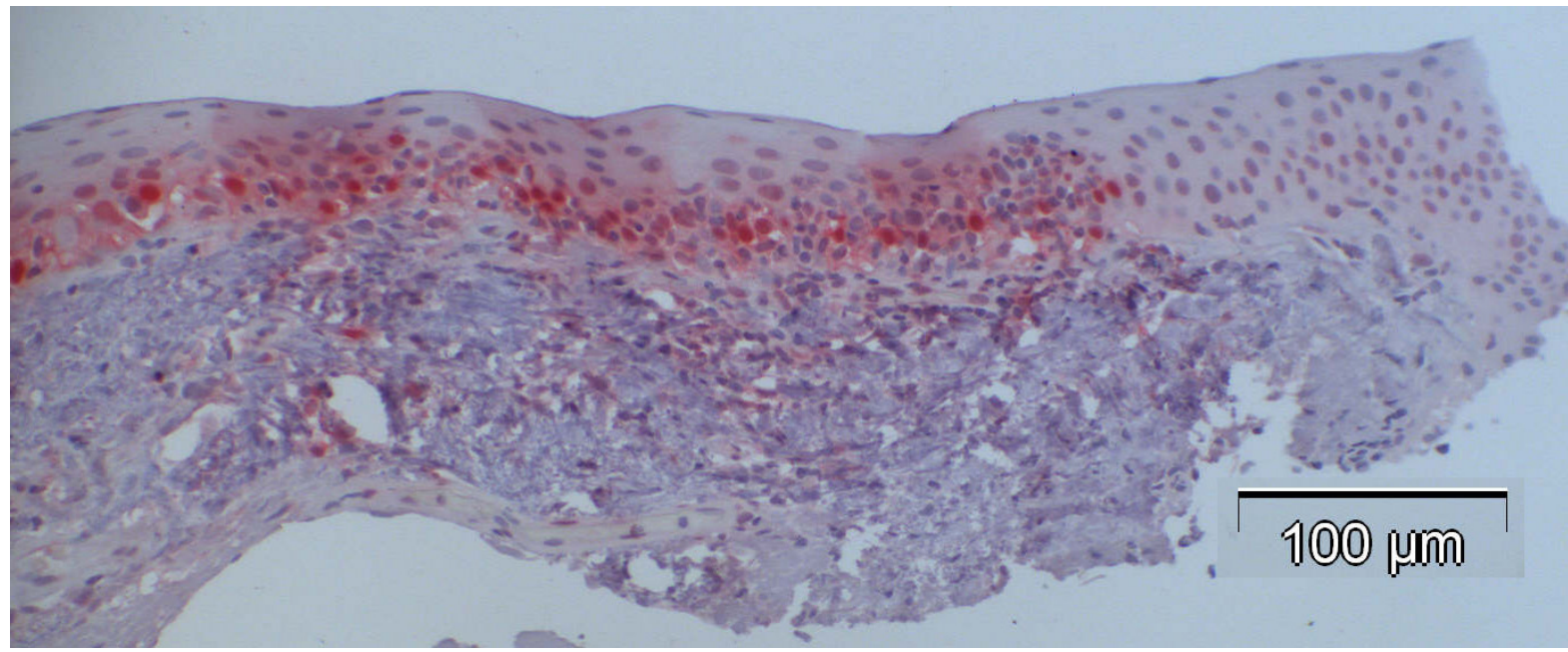

Fig. (4a). Case 2: CIN Grade I with dysplasia including the lower $25 \%$ of the whole epithelial thickness with p16-positivity of $51 \%$. 


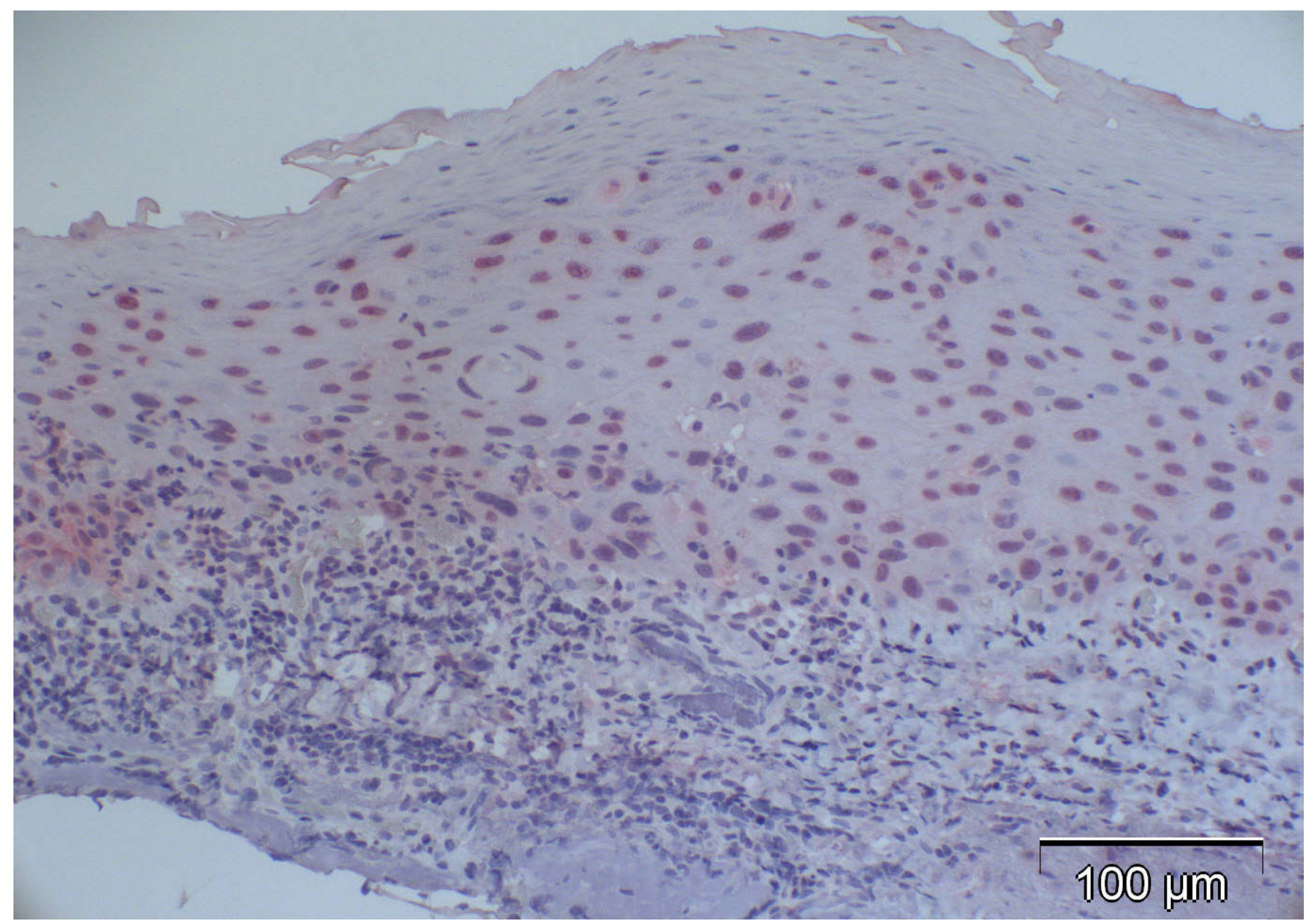

Fig. (4b). Case 3: CIN Grade II with dysplasia including the lower 75\% of the whole epithelial thickness with p16-positivity of 57\%.

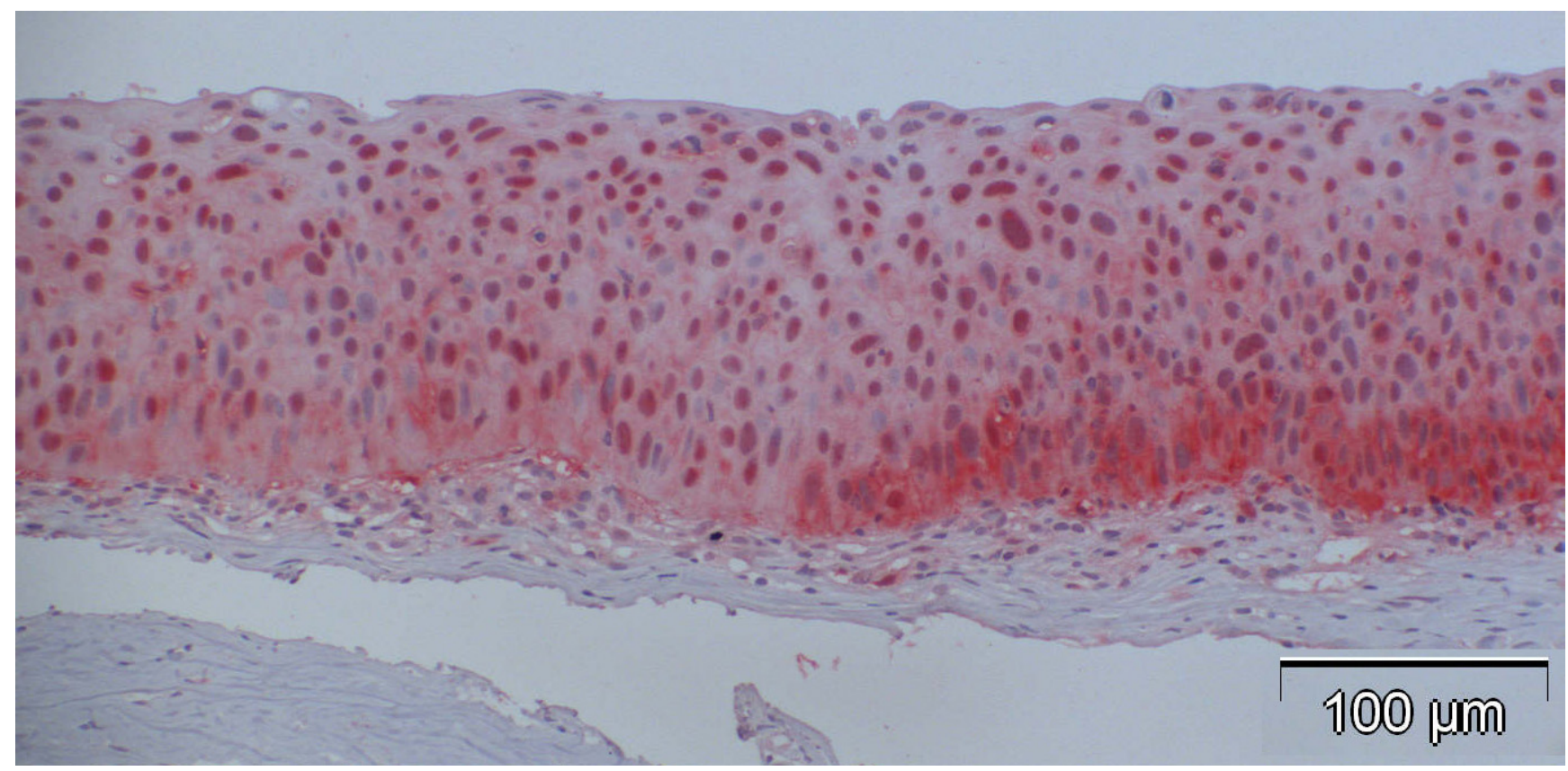

Fig. (4c). Case 8 from Table 3 (CIN III): $84 \%$ of the cells showed positive nuclear staining, and many of them also displayed cytoplasmic staining for 16 with higher intensity of basal compared to the more superficial layers. 


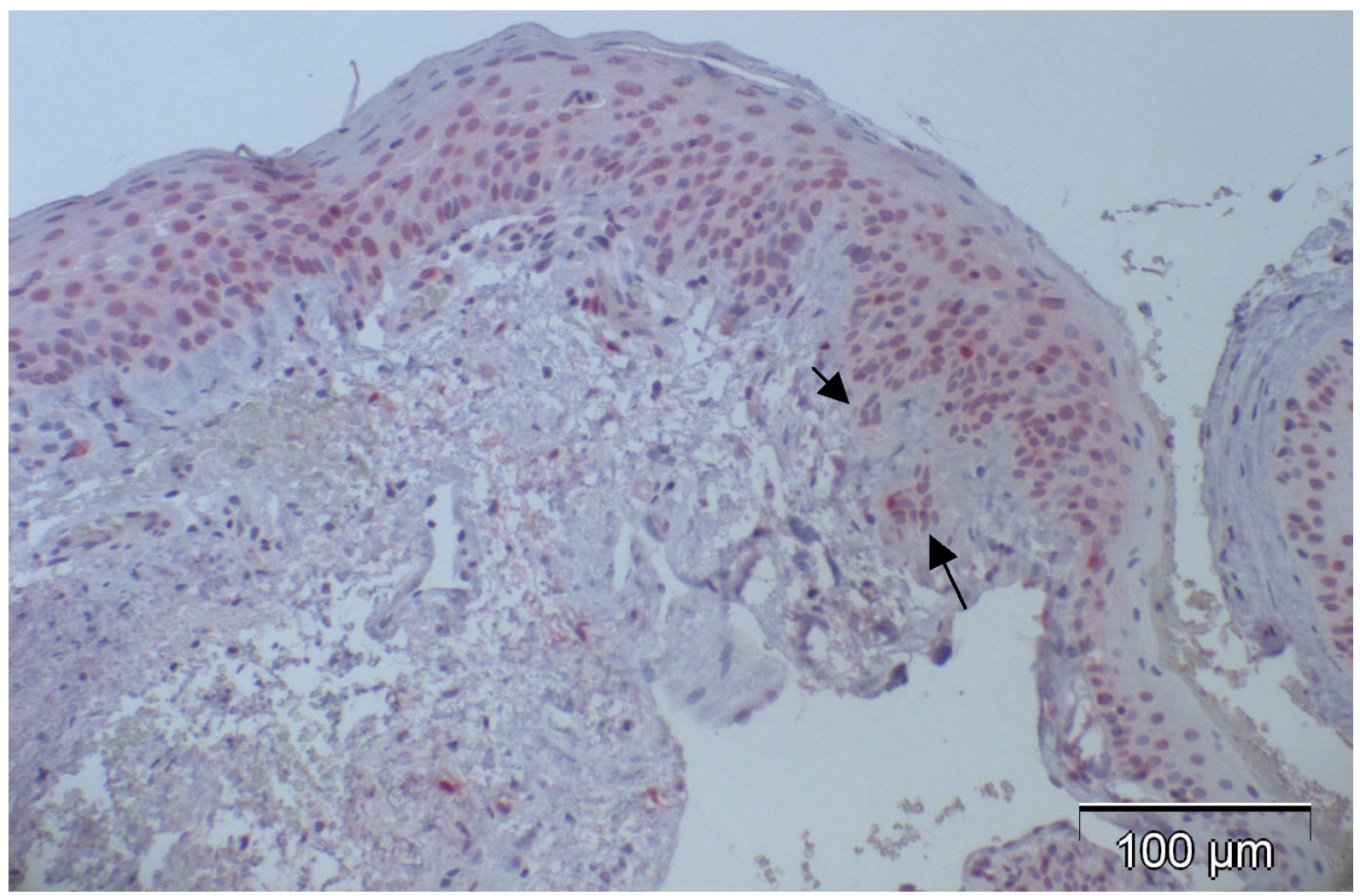

Fig. (4d). Case 12 from Table 3 (CIN with beginning invasion, arrows): 37\% of the cells showed positive nuclear staining.

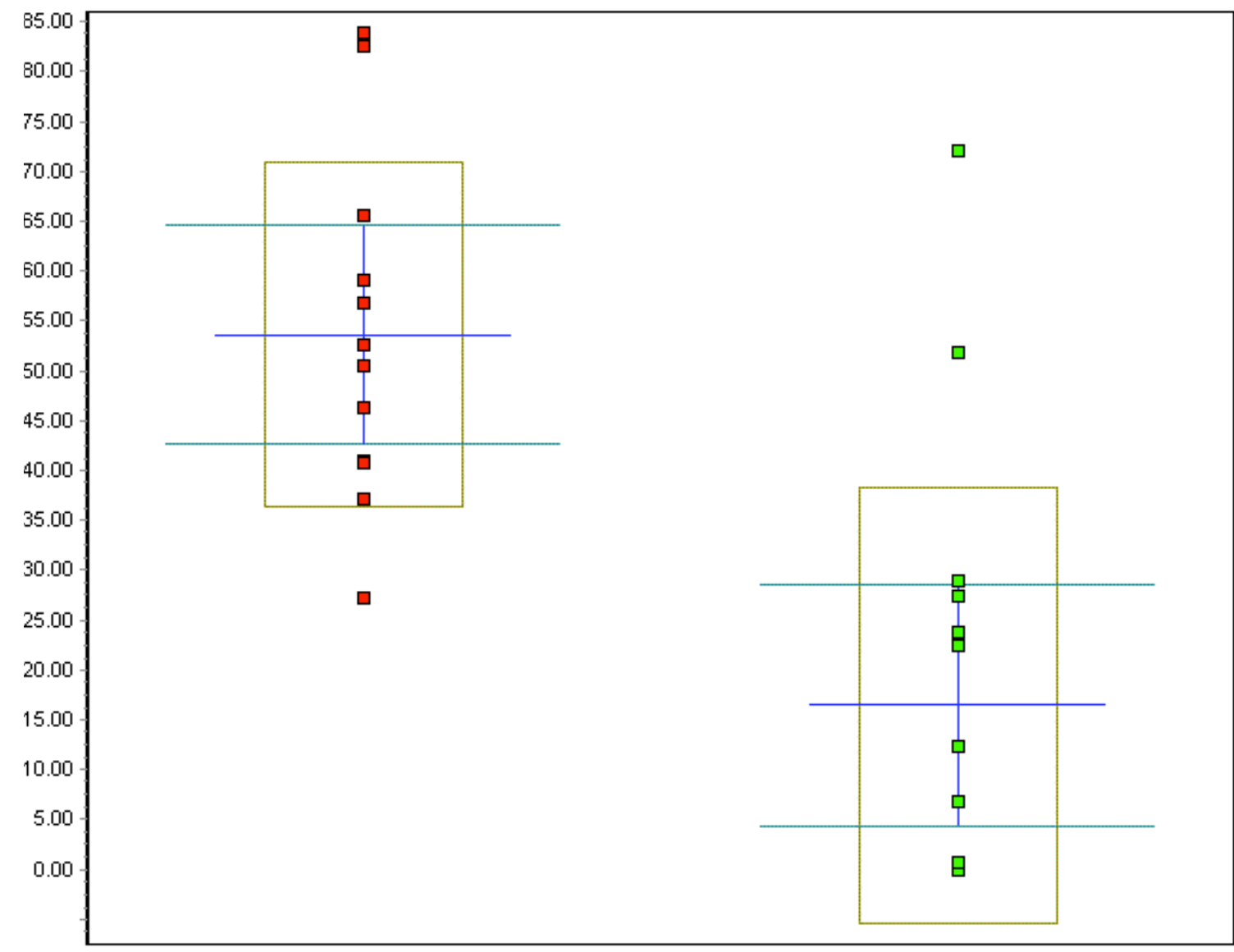

Fig. (5). Whisker plot of all p16 counts in \%: red dots represent the CIN cases, green dots represent the control cases, $\mathrm{p}<0.001$. 


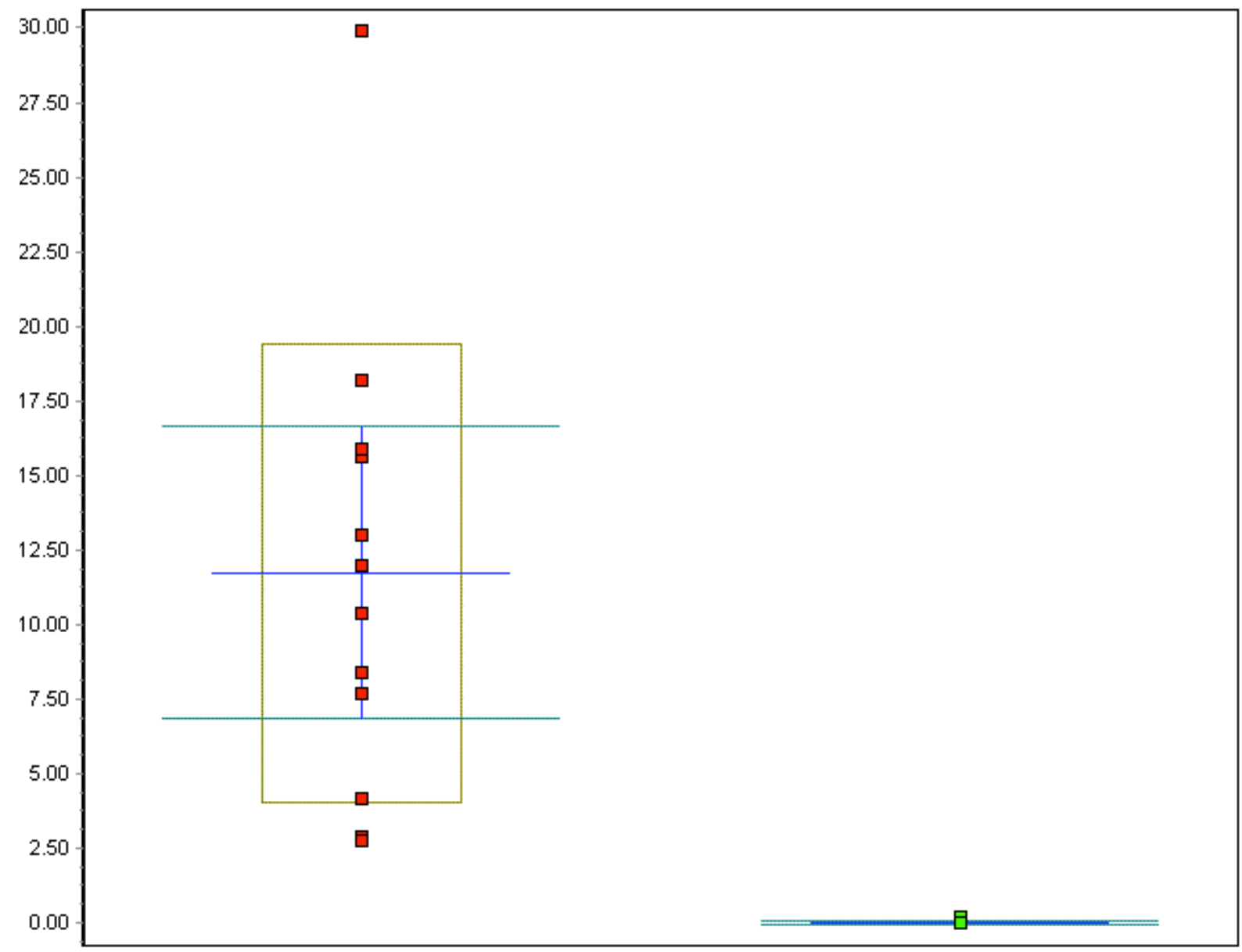

Fig. (6). Whisker plot of all Ki-67 counts in \%: red dots represent the CIN cases, green dots represent the control cases, $\mathrm{p}<0.001$.

Table 2. Normal Bulbar Conjunctival Specimens and the Proportion of p16 and MIB-1 Positive Cells

\begin{tabular}{|c|c|c|c|c|c|}
\hline No & p16-Positive Cells & MIB-1-Positive Cells & HPV & $\beta$-Actin & Postmortem Time $h=$ hours, ${ }^{b}=\min$ \\
\hline 1 & $6.8 \%(37 / 545)$ & $0 \%(1 / 500)$ & - & + & $23 \mathrm{~h} 40^{\prime}$ \\
\hline 2 & $0.1 \%(1 / 751)$ & $0 \%(0 / 500)$ & - & + & $<24 \mathrm{~h}$ \\
\hline 3 & $29.0 \%(228 / 785)$ & $0 \%(0 / 500)$ & - & + & $26 \mathrm{~h} 10^{\prime}$ \\
\hline 4 & $0.0 \%(0 / 750)$ & $0 \%(0 / 500)$ & - & + & $23 \mathrm{~h} 21^{\prime}$ \\
\hline 5 & $27.3 \%(241 / 883)$ & $0 \%(0 / 500)$ & - & + & $20 \mathrm{~h} 30^{\prime}$ \\
\hline 6 & $0.0 \%(0 / 750)$ & $0 \%(0 / 500)$ & - & + & $22 \mathrm{~h}$ \\
\hline 7 & $0.0 \%(0 / 750)$ & $0 \%(0 / 500)$ & - & + & $21 \mathrm{~h} 3^{\prime}$ \\
\hline 8 & $51.8 \%(309 / 597)$ & $0 \%(1 / 500)$ & - & + & $21 \mathrm{~h} 48^{\prime}$ \\
\hline 9 & $0.0 \%(0 / 500)$ & $0 \%(0 / 500)$ & - & - & $<24 \mathrm{~h}$ \\
\hline 10 & $0,0(0 / 500)$ & $0 \%(0 / 500$ & - & + & $10 \mathrm{~h}$ \\
\hline 11 & $22.5 \%(120 / 534)$ & $0 \%(1 / 500)$ & - & + & $15 \mathrm{~h} 5$ \\
\hline 12 & $72.1 \%(382 / 530)$ & $0 \%(0 / 500)$ & - & + & $20 \mathrm{~h} 20$ \\
\hline 13 & $12.4 \%(71 / 571)$ & n.a. & - & + & 0h (biopsy) \\
\hline 14 & $0.6 \%(3 / 503)$ & n.a. & - & + & $15 \mathrm{~h} 30^{\prime}$ \\
\hline 15 & $23.8 \%(121 / 509)$ & n.a. & - & + & $24 \mathrm{~h}$ \\
\hline Mean \pm SD & $16.43 \pm 21.87$ & $0.033 \pm 0.078$ & & & $18.2 \pm 7.1$ \\
\hline
\end{tabular}


Table 3. Differentiation Grade of the CIN Specimens and the Proportion of p16 and MIB-1 Positive Cells (Grade $4=$ CIN with Beginning Invasion)

\begin{tabular}{|c|c|c|c|c|c|}
\hline No. & Grade & p16-Positive Cells & MIB-1-Positive Cells & HPV & - \\
\hline \hline 1 & 1 & $66 \%(402 / 614)$ & $3 \%(15 / 510)$ & - \\
\hline 2 & 1 & $51 \%(263 / 521)$ & $4 \%(22 / 522)$ & - \\
\hline 3 & 2 & $57 \%(312 / 550)$ & $13 \%(72 / 552)$ & - \\
\hline 4 & 2 & $46 \%(258 / 558)$ & $16 \%(89 / 569)$ & - \\
\hline 5 & 2 & $41 \%(320 / 782)$ & $10 \%(72 / 694)$ & + \\
\hline 6 & 3 & $53 \%(378 / 720)$ & $16 \%(120 / 754)$ & + \\
\hline 7 & 3 & $41 \%(251 / 615)$ & $8 \%(70 / 831)$ & + \\
\hline 8 & 3 & $84 \%(536 / 639)$ & $18 \%(118 / 649)$ & $+($ type 16$)$ & + \\
\hline 9 & 3 & $59 \%(395 / 669)$ & $30 \%(183 / 613)$ & + \\
\hline 10 & 3 & $83 \%(598 / 725)$ & $12 \%(60 / 502)$ & + \\
\hline 11 & 4 & $27 \%(149 / 547)$ & $3 \%(15 / 539)$ & + \\
\hline 12 & 4 & $37 \%(247 / 664)$ & $8 \%(42 / 546)$ & + \\
\hline Mean \pm SD & & $53.6 \pm 17.3$ & $12 \% \pm 8 \%$ & + \\
\hline
\end{tabular}

controls. Only 2 of the CIN specimens (case 6 and 8) contained HPV type 16, and both were classified as grade III; eleven of the CIN specimens were found to express $\beta$-actin.

\section{DISCUSSION}

Cervical intraepithelial neoplasia has been shown to be associated with HPV-infection in more than $99 \%$ of the cases $[16,17]$. Infection of "high risk" strains, such as HPV $16,18,31,33,52$, and 58, is associated with more intense p16 expression in the infected cervical epithelial cells compared to "low risk" strains like HPV 6 or 11 [18]. Recent biological studies have revealed that $\mathrm{p} 16$ expression is markedly influenced by the status of $\mathrm{Rb}$ expression, and $\mathrm{p} 16$ overexpression has been demonstrated in cervical cancers, presumably due to the functional inactivation of $\mathrm{Rb}$ by human papillomavirus (HPV) E7 protein [18].

Our study shows increased p16 expression in conjunctival intraepithelial neoplasia compared to normal conjunctival specimens. This result is in contrast to that of Kuo et al. [19], whose CIN specimens were negative for p16 expression. Jung et al. found p16 elevated in conjunctival squamous cell carcinoma [20], which can develop from conjunctival intraepithelial neoplasia studied here. We assume that postmortem alterations of the control specimens with subsequent decreased immunoreactivity are not the reason for the significant elevation of p16 in CIN compared to the controls. Few control specimens showed even surprisingly high p16 expression despite their average or even higher than average postmortem time. Nevertheless, no correlation between $\mathrm{p} 16$ expression and differentiation grade was found, in contrast to the results described by Klaes et al. in cervical intraepithelial neoplasia [12]. This is possibly due to the low number of cases included in our study. The fact that few control specimens showed high p16 expression supported the hypothesis that this could be due to HPV-infection with $\mathrm{pRb}$ inactivation (see Fig. (1)) and subsequent p16 elevation. However, our results indicating the control specimens as HPV negative did not support the above-mentioned hypothesis. Furthermore, only 2 of the 12 CIN specimens turned out to be HPV positive, with type 16 detected. This is in line with the results of Tulvatana et al. who examined 30 CIN specimens and found negative HPV and positive $\beta$-globin DNA in 16 cases [21], and Eng et al., who did not find any HPV in 20 malignant epithelial conjunctival tumours [22]. In contrast, Scott et al. found HPV in 10 CIN cases (5 with HPV 16 and 5 with HPV 18) with negative results in the control specimens. In each of those CIN specimens, $20 \%-40 \%$ of dysplastic cells expressed HPV E6 [23]. These studies show that the etiology of CIN is not homogenous and in addition to HPV, other pathogens such as UV-radiation may play a role in CIN development.

In most of the cases presented here, p16 elevation was not found to be HPV-induced, but seems to be caused by another agent with or without the involvement of $\mathrm{pRb}$ status change. p16 did not correlate positively with differentiation grade and MIB-1-positivity, which might indicate that in some cells p16 elevation successfully prevented cell cycle progression beyond the restriction point.

In conclusion, p16 seems to be a malignancy indicator in conjunctival epithelial tumours, especially towards CIN, but caution must be applied as normal conjunctiva also occasionally displays high p16 expression. Our study shows that HPV is not the only oncogenic agent in CIN etiology and $\mathrm{HPV}$ vaccination seems not to prevent CIN in future.

\section{ACKNOWLEDGEMENTS}

We thank Mrs. Annegret Mattes and Mrs. Renate Buchen for technical assistance, and Dr. Johannes Hädrich and Dr. Daniel Böhringer for statistical analysis.

\section{REFERENCES}

[1] Lee GA, Hirst LW. Ocular Surface Squamous Neoplasia. Surv Ophthalmol 1995; 39: 429-450. 
[2] McDonnell JM, McDonnell PJ, Sun YY. Human papillomavirus DNA in tissues and ocular surface swabs of patients with conjunctival epithelial neoplasia. Invest Ophthamol Vis Sci 1992; 33: 184189.

[3] Lee GA, Williams G, Hirst LW, Green AC. Risk factors in the development of ocular surface epithelial dysplasia. Ophthalmology 1994; 101: 360-364.

[4] Trosko JE, Krause D, Isoun M. Sunlight-induced pyrimidine dimers in human cells in vitro. Nature 1970; 228: 358-359.

[5] Auw-Haedrich C, Sundmacher R, Freudenberg N, et al. Expression of p63 in conjunctival intraepithelial neoplasia and squamous carcinoma. Graefe's Arch Clin Exp Ophthalmol 2006; 244: 96-103.

[6] Yang A, Kaghad M, Wang Y, et al. p63, a p53 homolog at 3q2729 , encodes multiple products with transactivating, death-inducing, and dominant-negative activities. Mol Cell 1998; 2: 305-16.

[7] Quade BJ, Yang A, Wang Y, et al. Expression of the p53 homolpgue p63 in early cervical neoplasia. Gynecol Oncol 2001; 80: 2429.

[8] Aoyama C, Liu P, Ostrzega N, Holschneider CH. Histologic and immunohistochemical characteristics of neoplastic and nonneoplastic subgroups of atypical squamous lesions of the uterine cervix. Am J Clin Pathol 2005; 123: 699-706.

[9] Guimaraes MC, Goncalves MA, Soares CP, Bettini JS, Duarte RA, Soares EG. Immunohistochemical expression of p16INK4a abd bcl-2 according to HPV type and to the progression of cervical squamous intraepithelial lesions. J Histochem Cytochem 2005; 53: $509-16$.

[10] von Knebel Doeberitz M. New markers for cervical dysplasia to visualise the genomic chaos created by aberrant oncogenic papillomavirus infections. Eur J Cancer 2002; 38: 2229-42.

[11] Sano T, Masuda N, Oyama T, Nakajima T. Overexpression of p16 and p14ARF is associated with human papillomavirus infection in cervical squamous cell carcinoma and dysplasia. Pathol Int 2002; 52: $375-83$.

[12] Klaes R, Friedrich T, Spitkovsky D, et al. Overexpression of p16(INK4A) as a specific marker for dysplastic and neoplastic epithelial cells of the cervix uteri. Int J Cancer 2001; 92: 276-84.

[13] Coupland SE, Hellmich M, Auw-Haedrich C, Lee WR, Stein H. Prognostic value of cell-cycle markers in ocular adnexal lym- phoma: an assessment of 230 cases. Graefes Arch Clin Exp Ophthalmol 2004; 242: 130-145.

[14] Gravitt PE, Peyton CL, Alessi TQ, et al. Improved amplification of genital human papillomaviruses. J Clin Microbiol 2000; 38: 357361.

[15] Evans MF, Adamson CS, Simmons-Arnold L, Cooper K. Touchdown General Primer (GP5+/GP6+) PCR and optimized sample DNA concentration support the sensitive detection of human papillomavirus. BMC Clin Pathol 2005; 16: 10.

[16] Bosch FX, Lorincz A, Munoz N, Meijer CJ, Shah KV. The causal relation between human papillomavirus and cervical cancer. J Clin Pathol 2002; 55: 244-65.

[17] Bosch FX, Manos MM, Munoz N, et al. Prevalence of human papillomavirus in cervical cancer: a worldwide perspective. International biological study on cervical cancer (IBSCC) Study Group. J Natl Cancer Inst 1995; 87: 796-802.

[18] Sano T, Oyama T, Kashiwabara K, Fukuda T, Nakajima T. Expression status of $\mathrm{p} 16$ protein is associated with human papillomavirus oncogenic potential in cervical and genital lesions. Am J Pathol 1998; 153: 1741-8

[19] Kuo KT, Chang HC, Hsiao CH, Lin MC. Increased Ki-67 proliferative index and absence of P16INK4 in CIN-HPV related pathogenic pathways different from cervical squamous intraepithelial lesion. Br J Ophthalmol 2006; 90: 849-899.

[20] Jung SM, Lin HC, Chu PH, et al. Expression of cell cycleregulatory proteins, MIB-1, p16, p53, and p63, in squamous cell carcinoma of conjunctiva: not associated with human papillomavirus infection. Virchows Arch 2006; 448: 301-5.

[21] Tulvatana W, Bhattarakosol P, Sansopha L, et al. Risk factors for conjunctival squamous cell neoplasia: a matched case-control study. Br J Ophthalmol 2003; 87: 396-8.

[22] Eng HL, Lin TM, Chen SY, Wu SM, Chen WJ. Failure to detect human papillomavirus DNA in malignant epithelial neoplasms of conjunctiva by polymerase chain reaction. Am J Clin Pathol 2002; 117: 429-436.

[23] Scott IU, Karp CL, Nuovo GJ. Human papillomavirus 16 and 18 expression in conjunctival intraepithelial neoplasia. Ophthalmology 2002; 109: 542-547. 